\title{
OPEN WORD
}

\section{CODE OF ETHICS FOR TEACHERS: A DILEMMA}

\author{
PAULO FRAGA DA SILVA ${ }^{1}$ * \\ ORCID http://orcid.org/0000-0003-1446-6824 \\ IONE ISHII ${ }^{2 * *}$ \\ ORCID http://orcid.org/0000-0002-2304-5872 \\ MYRIAM KRASILCHIK ${ }^{2 * * *}$ \\ ORCID http://orcid.org/0000-0002-5277-840X
}

\begin{abstract}
Teacher training courses have been prioritizing the cognitive domain at the expense of the affective domain with a strong ethical component characteristic of the academic routine. Ethical dilemmas faced in the teaching practice inspired us to bring an overview of aspects addressed by the literature and some codes of ethics for teachers. Adopting these codes or not is a controversial issue. This text aims to bring up this controversy as a contribution to the professionalization of educators, so that they are able to anticipate ethical dilemmas situation at school, in its complexity and contradiction, giving them a better forwarding. Thus, it is expected that future teachers will be prepared to face these situations in students, colleagues and institutions relationship. An analysis of the dilemmas that there are at school can result in more fair decisions which also consider, besides to academic and institutional perspectives, the human aspects. Our proposal is that this discussion shall be broadly covered in teacher training courses.
\end{abstract}

Keywords: Ethics, Teacher Training, Codes Of Ethics, Values

\section{CÓDIGO DE ÉTICA DOCENTE: UM DILEMA}

RESUMO: Os cursos de formação docente têm priorizado o domínio cognitivo em detrimento do afetivo, com forte componente ético próprio do cotidiano acadêmico. A partir de dilemas éticos constatados no exercício docente, sentimos a necessidade de trazer um panorama dos aspectos abordados pela literatura pertinente ao tema e de alguns códigos de ética docente. A adoção ou não desses códigos é um tema polêmico. Este texto tem o objetivo de trazer à tona essa polêmica como contribuição para a profissionalização dos professores, para que eles sejam capazes de antecipar as situações de dilemas éticos que acontecem na escola, em sua complexidade e contradição, dando a estas um melhor encaminhamento. Com isso, espera-se que o futuro professor esteja mais preparado para o enfrentamento dessas situações no relacionamento com os alunos, os colegas e as instituições. A análise dos dilemas existentes na escola pode resultar em decisões mais justas que considerem, além das perspectivas acadêmicas e institucionais, também os aspectos humanos. Nossa proposta é a de que essa discussão seja amplamente abordada nos cursos de formação docente.

\footnotetext{
${ }^{1}$ Universidade Presbiteriana Mackenzie, São Paulo, SP - Brasil

* Doutor, Professor Adjunto da Universidade Presbiteriana Mackenzie. E-mail: <paulofragadasilva@gmail.com>.

2 Universidade de São Paulo, São Paulo, SP - Brasil

** Doutora, Professora da Rede Pública Estadual de São Paulo. E-mail: <ioneishii@uol.com.br>.

*** Doutora, Professora Emérita e Titular da Faculdade de Educação da Universidade de São Paulo. E-mail: <mkrasilc@usp.br>
} 
Palavras-chave: Ética, Formação Docente, Códigos de Ética, Valores

\section{CÓDIGO DE ÉTICA DOCENTE: UN DILEMA}

RESÚMEN: Los cursos de formación docente vienen priorizando el dominio cognitivo en detrimento del afectivo, con un fuerte componente ético propio del cotidiano académico. A partir de dilemas éticos constatados en el ejercicio docente, sentimos la necesidad de traer un panorama de los aspectos abordados por la literatura pertinente a la temática y de algunos códigos de ética docente. La adopción o no de esos códigos es un tema polémico. Este texto tiene el objetivo de traer a la luz esa polémica como contribución para la profesionalización de los profesores, para que ellos sean capaces de anticipar las situaciones de dilemas éticos que ocurren en la escuela, en su complejidad y contradicción, dándole a ésas un mejor encaminamiento. Con eso, se espera que el futuro profesor esté más preparado para el enfrentamiento de esas situaciones en la relación con los alumnos, los colegas y las instituciones. El análisis de los dilemas existentes en la escuela puede resultar en decisiones más justas que consideren, además de las perspectivas académicas e institucionales, también los aspectos humanos. Nuestra propuesta es la de que esa discusión sea ampliamente abordada en los cursos de formación docente.

Palabras clave: Ética, Formación Docente; Códigos de Ética, Valores

\section{INTRODUCTION}

(Bio)ethical issues, balance and environmental sustainability are nowadays widespread in the media and social media, but seldom day-to-day teaching issues are recognized as ethical dilemmas.

The work of a teacher consists of a multifaceted set of activities that are traditionally recognized: preparing classes, participating in teams for planning practical work and evaluation, observing and advising students, among others. At the same time, professionals, officers, students and their families are not always clear on situations in the school and academic context that may cause perplexity, uncertainties, doubts, disagreements and controversies.

In an exercise with graduate students, one of the difficulties we recognized is identifying an ethical dilemma to be analyzed. The activity consisted of discussing a case in Germany of infection caused by bacteria allegedly present in vegetable imported from Spain. The German authorities issued a warning to the citizens not to consume the vegetable allegedly contaminated. After analysis, it was verified that the hypothesis was unfounded, since the infection was caused by vegetable produced in Germany itself, thus causing great damages to the producer country supposedly responsible for the dissemination of the microorganism ${ }^{1}$.

When discussing the case to identify the dilemma, the students focused on geopolitical issues and found it difficult to get to the core of ethical question, that is, the dilemma: disclose a hypothesis of unconfirmed contamination or wait for the analysis results, increasing the health risk of consumers, avoiding economic and diplomatic losses with Spanish producers.

During the discussion on the case, from the identification of the dilemma, similar cases experienced by the students were presented, which leads us to consider that such situations are recurring in the daily life, also in the teaching routine, even though they are seldom perceived and properly analyzed.

The teaching activity requires quick thinking, without clear identification and weighting of issues, which leads to decisions that may result in serious consequences. 
Exemplifying issues commonly occurring in the classroom, in the school and academic environment, for which there are no clear answers and rules, would result in a preventive effort in teacher preparation, allowing the teacher to assume their values and beliefs, and act accordingly, even though many have difficulty identifying an ethical dilemma.

According to Ferreira (2010) the autonomy, the possibility of decision-making, by itself, does not ensure ethical decision-making. Applied ethics only occurs in relation to others, since it requires knowledge about one's own values, principles, standards, identity. Haldane (2013), proposes the need to distinguish Morality, Moral Theory and Metaethics. Briefly, Morality is considered as a body of moral theses expressing a certain type of concern accompanied by principles justifying such theses. The articulation of such principles in a systematic structure is what constitutes the Moral Theory. Metathetics, however, concerns the logical status of moral theories. Thus, according to the author, the central aspect of applied ethics consists in the somewhat systematic application of a Moral Theory to specific moral issues (Morality).

Therefore, addressing the dilemmas and ethical decisions that are part of the professional life of the teacher, intuitively only, is to disregard all the complexity involved in the decision-making exercise. According to Cortina (2005), applied ethics consists in the application of ethical principles, whether in the utilitarian, Kantian or dialogical perspective, ascertaining how these principles can help guide the different types of activities. In this application, it is necessary to take into account that each type of activity has its own moral requirements and its own specific values. The author stresses that ethicists need to develop it cooperatively with the experts in each field, therefore, applied ethics is necessarily interdisciplinary.

The teacher training programs, both for basic and higher education, have prioritized the cognitive domain and end up ignoring questions of the affective domain characteristic of the school and academic routine, many of which present a strong ethical component. In studies on the teachers' perception of their training, most of the respondents understand that, throughout the graduation, there is a greater emphasis on informative aspects and predominant concern with intellectual and technical training. A small portion understands that the courses give greater emphasis to the training and creative aspects, providing the development of a more ethical and critical world perception (SILVA, 2008).

Several professional areas have their own code of ethics. If applicable, the codes of ethics for teachers are associated with the institutions where teachers exercise their profession, unlike other professions which have their own codes not associated with any establishment. In times of compliance5, it is worth asking if this resource presents a strong ethical-moral component. We emphasize that when discussing ethical aspects of daily teaching, we want to lose sight of the legality extent and reflect on the legitimacy of the discussions raised herein.

Few researchers have been challenged or even dedicated in their studies to consider the ethical issues inherent in the teaching profession.

Denisova-Schmidt (2016) stresses the challenge of maintaining academic integrity against recurring situations, such as: fraud in class attendance, improper substitution by colleagues or strangers in conducting tests or work, plagiarism, use of bribe to facilitate admission to course programs, obtaining copies of exams and tests in advance, use of unauthorized materials or tools during exams, obtaining monographs or other documents from the Internet, presentation of false documentation. This reveals the pertinence of academic integrity as a current ethical dilemma.

From a set of ethical dilemmas faced in the teaching exercise, we feel the need to present an overview of aspects addressed by the literature and codes of ethics for teachers. Applying these codes or not is a controversial issue. Thus, the text aims to bring up this controversy as a contribution to the training of educators ${ }^{2}$.

\section{WHAT SOME AUTHORS SAY}


We make ethical decisions on a daily basis, consciously or otherwise, based on our values and often not clearly identified by us. Faced with a pluralism of society, which also falls on ethical and moral aspects, it is to be expected that many will not share the same values, that is, they will disagree with our decisions, leading to conflicts. The ethical-moral approach can be "an aptitude for the peaceful solution of conflicts" (CORTINA, 2005, p. 36). The source of the conflict lies in the disharmony between the subjective ends with the ends of the social group and in the antagonistic interests of the different social groups, thus "the novelty would be to situate the moral sphere preferentially in the resolution of conflicts of action, whether at the individual level or at the collective level" (CORTINA, 2005, p. 37). Ferreira (2010, p. 28-29) adds that conflict is part of the human condition, defined as "a painful process of thinking difference as a possibility".

Considering that there are no ready answers to the complicated situations faced by a teacher, what can be offered are ways of thinking about such questions.

It should be noted that not all ethical issues are ethical dilemmas. According to Anderson (2001), individuals engage in clearly illegal or unethical acts, such as lying, stealing or falsifying documents. A teacher who dismisses the negative evaluations of his or her students and presents only the positive ones is an example of an unethical act. The dilemma must have occurred earlier, when the teacher considered: do I submit all evaluations? Or do I discard the negative evaluations in order to be better evaluated by the commission on promotion and stability in the institution? Thus, the teacher's unethical decision to exclude the negative evaluations took into consideration his or her condition of father or mother to preserve his or her job.

In terms of greater good or the "right" thing to do, it would be easy to rationalize that providing for one's family would be so fair, and possibly more "correct," than to be ethical in this situation. After all, one could argue that no one would be harmed by failing to report caustic comments from some disgruntled students (ANDERSON, 2001, p. 309, free translation).

Again, a dilemma implies a choice between two or more equally balanced alternatives for solving an ethical issue. Dilemmas are difficult issues, with no clear rules, placing the individual in a situation of doubt and uncertainty. They only occur when reality demands principles that the subject considered fundamental for his or her life, that is, when they are placed under suspicion in situations in which he or she chose between two or more principles and values that he or she considered immutable, fundamental to the exercise of autonomy (FERREIRA, 2010). The dilemma may arise in different contexts, among which, the professional. Often, the person is torn between a rational choice (what he or she is supposed to do) and an emotional choice (what he or she feels he or she wants to do).

Anderson (2001) proposes a logical approach to address ethical dilemmas. The first step is to identify the educator's own values. To this end, the author raises some questions: when violating certain values, will we feel sad or guilty? Which values do we consider most important?

According to the author, the singular principle that should guide all views and decisions of teachers is the basic respect for the students. It is noticeable that students are different from each other, not only in relation to age, intellectual level, the will to learn, but also in honesty and integrity.

Teachers develop stereotypes about students, which involve a load of prejudices. Thus, they have their preferences to work with certain types of students, however, we must recall that all of them indistinctly deserve respect and dedication.

It the teacher's duty not to be influenced by predetermined views. The analysis of their own prejudices regarding gender, human and cultural diversity leads to the improvement of the conduct of all those involved in the educational process.

Anderson (2001) categorizes decision-making as absolutist or relativistic views. According to the author, the educator who respects the rules without considering the possibility of changing them or the existence of exceptions, regardless of context, is absolutist with 
arguments based solely on justice. In Kohlberg's view (1984), this subject would be at a stage characterized by the maintenance of order. The attitude is not only of conformity, but of loyalty to the expectations of the social order. It is a question of maintaining, sustaining and actively justifying this order, in a certain kind of legalism.

On the other hand, relativists take into account the context and individual circumstances to make a decision. The relativist is, perhaps, closer to principled decisions, characterized by Kohlberg (1984) as the postconventional level. In it, there is a clear perception of the relativity of personal values and an emphasis on procedural rules in the pursuit of a consensus that must be observed as they are part of the social contract. The social-moral perspective adopted by the subject is that of the relative priority of the individual in relation to the social. The subject considers the moral and legal points of view, but recognizes that sometimes they collide and do not integrate easily.

Kohlberg continued the studies of Piaget addressing moral reasoning in adolescents and young adults. As Piaget, Kohlberg (1984) points out an invariant sequence of six moral stages at three major levels of morality: the preconventional, the conventional, and the postconventional. According to him, the structuring of the moral conscience occurs at increasingly high and balanced levels arising from the interaction of individuals with the their environment. He considered the existence of a set of moral principles that are accepted as valid and universal, regardless of specific cultures.

It should be noted that treating all students with a basic respect attitude should be the beginning of a teaching ethic stance, but not enough to solve ethical dilemmas. Courage and a sense of duty are essential requirements for the ethical exercise of any school and academic activity.

What cannot be disregarded is the authority that teachers have and how their actions affect students' lives, whether by words or attitudes.

In addition to basic respect for students, and in order not to abuse this power, there are other principles that can be applied when faced with ethical dilemmas and issues. These principles are related to the traditional theoretical current of Bioethics called principlism, emerging from the concern with the social control of human research. These principles, present in the Belmont Report are: autonomy, beneficence and justice. Principlism also had as representatives Beauchamp and Childress (1979), who published a reference work6 in which they reworked the three principles into "four", distinguishing beneficence and non-maleficence, becoming the main theoretical foundation of bioethics, considered as applied ethics.

Autonomy is not a univocal concept. Many ideas comprise the concept under the philosophical perspective adopted, for which reason it is necessary to refine it in its light. The autonomous individual, according to Beauchamp and Childress (2002), is able to act freely according to a plan chosen by him or her, with knowledge of cause and without external coercion. Respect for people's autonomy is as deeply embedded in common morality as any other principle.

Ferreira (2010, p. 27), when discussing applied ethics, states that "the subject is autonomous when, upon facing established standards, he or she internalizes them and, in reflecting on the possible consequences of his or her decisions, makes choices".

Anderson (2001) stresses the care teachers must take in not imposing their point of view, values or preferences on students, not forgetting their potential ability to coerce. The authority exercised by the teacher may minimize the autonomy of the student, which must be respected.

In the principle of beneficence, principlism rejects the classical idea of beneficence as charity and considers it as an obligation. In this sense, maximizing the benefits of an action and minimizing its potential risks comprises one of its characteristics ${ }^{3}$.

Beauchamp and Childress (2002) state that the beneficent action should be understood in a broad sense so as to include all forms of action that are intended to benefit 
others. In the academic and classroom context, constructive criticism is more useful than destructive criticism. If there are dilemmas where it is not always possible to do good, choose the option causing as little harm as possible.

Beauchamp and Childress (2002) distinguish beneficence from non-maleficence. Thus, they consider non-maleficence as not causing harm or the obligation not to inflict harm intentionally, emphasizing it as an imperative. Teachers' self-esteem and patience are tested when students say unpleasant things or make accusations, so as Anderson (2001) points out, one should not deliberately fight back or 'give a taste of one's own medicine'.

Bioethical principlism understands justice as 'fairness in the distribution of risks and benefits' or 'equals must be treated equally, and the unequals must be treated unequally', with emphasis on equity. The principle of justice is what drives us to ensure fair, equitable and universal distribution of the benefits of an action, that is, justice as a fair treatment, considering what is due to the people. Such aspects have implications for the classroom. Students want fair treatment, that is, they do not want colleagues having special treatment or privileges. They do not accept that, for instance, in a group activity, one who did not make any effort and those who make efforts score the same grade. Students expect rules to govern their behavior, and are more sensitive to iniquity in its various forms (ANDERSON, 2001).

The last and essential principle that can be applied when we are faced with ethical dilemmas is veracity, without which there is no possibility that an educator is seen as an ethical individual. Although there are many interpretations of what the truth is, a compromise is required, distinguishing what we have seen from what we think or believe, preventing a fact from becoming twisted or misrepresented. Anderson (2001) goes on to state that, promising something we cannot keep is also similar to lying, therefore, unethical. Honesty is the best stance, even if it is embarrassing or even painful.

These principles may refer to Kohlberg's concept of moral judgment competence formulated in 1964, which defines it as "the ability to make decisions and judge morally based on internal principles and to act in accordance with those judgments" (LIND, 2018, p. 1). According to Lind (2018), moral competence is the bridge between good moral intentions and moral behavior.

For Piaget (1996), interpersonal relations play a central role in the development of the individual's moral personality. Such relations may be based on unilateral respect, resulting in the moral of coercion; or on a mutual respect, fruit of relations between equals, characteristic of the morality of cooperation. The moral of coercion and moral of cooperation correspond to the heteronomous and autonomous stages, respectively.

It is important to emphasize that the institutional affective environment influences, directly and indirectly, the development of professionals' moral competence. In our case, the environment of early teacher training can contribute to the development of such competence and to the exercise of decision-making.

As Piaget, Kohlberg (1984) states that affective and cognitive properties are distinct, however, they are inseparable aspects of moral behavior. According to him, the moral act cannot be defined by purely cognitive or motivational criteria.

\section{WHAT SOME CODES OF ETHICS SAY}

The multifaceted complexity of the teaching activity is the subject to codes of ethics assuming diverse forms in structure, content and function.

In order to verify how codes of ethics are presented in different countries, a brief survey was carried out, based on those available online, in Portuguese, English and Spanish.

We found documents from different countries (United States, New Zealand, Peru, Brazil, Malta) in the form of general guidelines, manuals, legal documents on government websites, professional associations and universities. 
Boxes 1 and 2 present principles and obligations of codes of ethics of teaching and government associations cited in the documents surveyed. The general organization of these documents reveals a wide variety: they address relationships with students, with colleagues, with institutions with which they are associated, with education systems, with families and with society.

BOX 1 - Standards, obligations and principles presented by codes of ethics of teaching associations in different countries

\begin{tabular}{|c|c|c|}
\hline COUNTRY & ASSOCIATION & STANDARDS/OBLIGATIONS/PRINCIPLES \\
\hline \multirow{5}{*}{ United States } & $\begin{array}{l}\text { Association of American } \\
\text { Educators (AAE) }\end{array}$ & $\begin{array}{l}\text { Ethical conduct towards students in relation to practices } \\
\text { and performance, with co-workers, parents/guardians, } \\
\text { and the community }\end{array}$ \\
\hline & $\begin{array}{l}\text { National Association of State } \\
\text { Directors of Teachers } \\
\text { Education and Certification } \\
\text { (NASDTEC) }^{5}\end{array}$ & $\begin{array}{l}\text { Responsibility towards the profession, students, the } \\
\text { school community, and ethics in the use of technology } \\
\text { Professional competence }\end{array}$ \\
\hline & $\begin{array}{l}\text { National Education } \\
\text { Association (NEA) }\end{array}$ & Commitment to students and profession \\
\hline & $\begin{array}{l}\text { The University of State of } \\
\text { New York/ The State } \\
\text { Education Department/ New } \\
\text { York State Professional } \\
\text { Standards and Practice Board } \\
\text { for Teaching } 7\end{array}$ & $\begin{array}{l}\text { Educators stimulate the intellectual, physical, emotional, } \\
\text { social and civic potential of each student; create, } \\
\text { support and maintain challenging environments for all; } \\
\text { are committed to their own training in order to develop } \\
\text { their practice; collaborate with colleagues and other } \\
\text { professionals with an interest in student learning; } \\
\text { collaborate with parents and the community, building } \\
\text { trust and respecting confidentiality; advance the } \\
\text { intellectual and ethical basis of the learning community. }\end{array}$ \\
\hline & $\begin{array}{l}\text { Georgia Professional } \\
\text { Standards Commission } 8\end{array}$ & $\begin{array}{l}\text { Legal compliance } \\
\text { Conduct with students } \\
\text { Alcohol and Drugs } \\
\text { Honesty } \\
\text { Public funds and property } \\
\text { Compensation conduct } \\
\text { Confidential Information } \\
\text { Discontinuance of agreement } \\
\text { Reports required } \\
\text { Professional conduct } \\
\text { Evidence }\end{array}$ \\
\hline New Zealand & $\begin{array}{l}\text { The Education Council Code } \\
\text { of Ethics for Certificated } \\
\text { Teachers } 9\end{array}$ & $\begin{array}{l}\text { Commitment to students, parents, guardians, } \\
\text { family/whanau, society, profession }\end{array}$ \\
\hline Peru & $\begin{array}{l}\text { Colegio Profesional de } \\
\text { Professores del Peru } 10\end{array}$ & $\begin{array}{l}\text { General principles: veracity, justice, work, and honesty } \\
\text { Teacher's role } \\
\text { Communication between teachers and students } \\
\text { Common objectives between parents and teachers } \\
\text { Relationship of teachers with state-owned education } \\
\text { agencies } \\
\text { Relationships between teachers; of teachers with the } \\
\text { community, institutions and the state. }\end{array}$ \\
\hline Brazil & $\begin{array}{l}\text { Insper - Ensino superior em } \\
\text { negócios, direito e engenharia } \\
11\end{array}$ & $\begin{array}{l}\text { Values: honesty and integrity } \\
\text { Principles: commitment, mutual trust, responsibility, } \\
\text { appreciation of diversity }\end{array}$ \\
\hline
\end{tabular}


Source: produced by the authors from codes of ethics consulted on the internet. See bibliographic references.

BOX 2 - Standards, obligations and principles presented by government codes of ethics in different countries

\begin{tabular}{|c|c|c|}
\hline COUNTRY & INSTITUTION & STANDARDS/OBLIGATIONS/PRINCIPLES \\
\hline \multirow{3}{*}{ United States } & $\begin{array}{l}\text { Connecticut Code of } \\
\text { Professional Responsibility } \\
\text { for Teachers } 121314\end{array}$ & $\begin{array}{l}\text { Responsibility towards the student, the profession, } \\
\text { the community }\end{array}$ \\
\hline & $\begin{array}{l}\text { Florida Department of } \\
\text { Education } 15\end{array}$ & Ethical and disciplinary principles \\
\hline & $\begin{array}{l}\text { Michigan Department of } \\
\text { Education } 16\end{array}$ & $\begin{array}{l}\text { Service for the common good } \\
\text { Mutual respect } \\
\text { Equity } \\
\text { Diversity } \\
\text { Veracity and Honesty }\end{array}$ \\
\hline Malta & $\begin{array}{l}\text { Ministry of Education and } \\
\text { Employment }{ }^{17}\end{array}$ & $\begin{array}{l}\text { Maintaining confidence in the profession } \\
\text { Maintaining professional relationships with students } \\
\text { Respect for students' uniqueness and diversity } \\
\text { Work collaboratively with colleagues, parents, } \\
\text { guardians } \\
\text { Acting with honesty and integrity } \\
\text { Maintaining professional and practical knowledge up } \\
\text { to date }\end{array}$ \\
\hline
\end{tabular}

Source: produced by the authors from codes of ethics consulted on the internet. See bibliographic references.

The analysis of these documents allows us to identify some common trends. Some of the codes establish principles and standards to evaluate the conduct of educators which, in extreme cases, may lead to the exclusion of the professional and revocation of their certificate to teach.

Depending on their origin, codes of ethics have different characteristics. Those of government institutions are rigid and stipulate penalties for offenders. Those of professional associations have an educational nature and seek to maintain a technical and academic standard.

Some, such as New Zealand's code of ethics for certified teachers, dictate that teachers must obey the law. It is interesting to note the concern with inclusivity in the system, evidenced by the mention of natives, of the Maori people. The code also indicates that the teacher needs to seek lifelong professional development and assist beginning teachers. This last point refers to mentorship - a recurrent topic in the discussions in Brazil about the training, development and professional permanence of beginning teachers (TANCREDI; REALI; MIZUKAMI, 2008).

The Florida Department of Education presents, in addition to ethical principles, disciplinary measures for behaviors outside established standards. It emphasizes the need to ensure independence of action to the student in the pursuit of learning and access to different points of view, as well as providing well-selected and relevant information in order to meet the objectives of the course with quality.

Certain codes such as that of the Georgia Professional Standards Commission reflect the concern with ensuring technical procedures legitimized by the professionals themselves.

Others, such as that of the University of State of New York, aims to guide the work of educators by encouraging the intellectual and ethical development of students, educators and colleagues while maintaining an environment of respect, diversity and confidentiality.

The National Association of State of Directors of Teachers Education and Certification (NASDTEC) introduced in its document prepared in 2015 the concern for the 
ethical use of technology, a topic that will surely become an increasing source of problems for educators. The use of electronic equipment in class as a source of distraction and the possibility of plagiarism in their use are mentioned as a permanent source of conflicts, as pointed out by Denisova-Schmidt (2016). In addition, it reinforces the need to update ethical decisions and principles from significant sources, including institutions and professional organizations, for the development of quality and assurance of professional efficiency.

The National Education Association (NEA) establishes at least two types of commitment: with the student and with the profession. In relation to the former, it suggests not suppressing deliberately or misrepresenting the content of education relevant to the student's progress, as well as protecting it from conditions detrimental to health and learning. It also proposes to avoid placing the student in situations of embarrassment or depreciation, either by exclusion, denying benefits, offering or granting personal advantages. Addressing the diversity of students' learning styles, selecting content from different sources, emphasizing the constant need for improvement for professional growth.

The codes call attention to the need for honesty in presenting their own qualifications and cooperation with colleagues to ensure success in student learning and the pursuit of research advances. Freedom of choice of ideologies and content and prevention of actions that violate professional integrity are included in many of these documents.

Special chapters are devoted to the importance of family and community participation, in order to report information about the students and ensure respect for the different cultures present in the classes.

It is important to note the identification of principles and values in the codes presented, such as: responsibility, honesty, trust, commitment, integrity, respect, truth, confidentiality, justice and equity, some of which were indicated by Anderson (2001) and Beauchamp and Childress (2002). In addition, teachers are expected to focus on student learning, valuing their potential and, for that, they must maintain a challenging environment.

The lack of codes of ethics for the teaching profession in Brazil should be discussed in the academic community, and also as one of the contents to be addressed in teacher training.

Veiga et al. (2005), when addressing teacher professionalization, emphasize that codes of ethics can limit individual freedom, promote vigilance and control actions by professional entities that could be established due to the implementation of such codes, as it happens with other professions. On the other hand, the same author affirms that reflections on professional ethics express an achievement of the profession's identity. Thus, codes of ethics should be a means and not an end in itself, identifying values and principles that guide the teaching activity.

\section{FINAL CONSIDERATIONS}

In view of the foregoing, the future teacher is expected to be prepared to face dilemma situations in the relationship with students, colleagues and institutions. Thus, we intend that the text contributes to the development of an early teacher training environment that is more predictive about what happens at school, in its complexity and contradiction. The analysis of existing dilemmas may result in fairer decisions that consider, in addition to academic and institutional perspectives, human aspects as well.

It should be noted that most of the codes of ethics analyzed have an approach based on principles and values that may favor a positioning close to a relativistic stance. Identifying the principles and values underlying codes of ethics is one way of approaching the development of the moral sense. In this regard, bringing the analysis and discussion of these codes to teacher training courses would be a contribution in the teaching and learning of fundamental values, which are inherent to the teaching profession. Kohlberg and Piaget point out that discussion 
environments, dialogically and democratically, favor the achievement of more autonomous stages suitable to the development of the moral sense.

It is essential that the topic becomes part of the teacher training syllabus. To this end, the existence of a code of professional ethics, according to a few, would be a provocative element in the discussion. In addition to becoming acquainted with such code, those involved would contribute to its continuous improvement. According to others, the existence of a code would cause the topic to be less flexible with rigid rules which would prevent its discussion.

At any rate, we think that students should be warned that academic relationships are not limited to expositions of content, demonstrations and practical activities. They also involve other responsibilities resulting from issues that arise therefrom and the impact of decisions on students, colleagues, and institutions.

In undergraduate courses, teachers should encourage students to collect examples of dilemma cases, report them in class, and promote dialogue about what defines a dilemma and possible consequences of alternative decisions.

In this sense, moments of reflection are encouraged, as to contribute to the preparation, prevention and creation of a list of possible questions that may arise, constituting moments that can challenge the personal beliefs of future teachers. According to Tardif (2000), it is this personal knowledge that ends up guiding the professional practice, since teachers have not been able to relate the academic knowledge to the teaching practice.

For discussions to achieve these goals, it is essential to establish an environment of free participation, in which those involved are free to express disagreements, controversies, doubts without fear of censorship or retaliation.

Therefore, our proposal is to broadly discuss, in undergraduate courses, the implications of the existence or inexistence of codes of ethics for educators.

\section{REFERÊNCIAS}

ANDERSON, D. Values and Ethics. In: ROYSE, D. Teaching tips for College and University Instructors. A practical Guide. A Person Education Company: Needham Heights, MA, 2001.

BEAUCHAMP, T. L.; CHILDRESS, J. F. Principles of biomedical ethics. New York: Oxford University Press, 1979.

BEAUCHAMP, T. L.; CHILDRESS, J. F. Princípios de ética biomédica. São Paulo: Edições Loyola, 2002.

CORTINA, A.; MARTINEZ, E. Ética. São Paulo: Loyola, 2005.

DENISOVA-SCHMIDT, E. The Global Challenge of Academic Integrity. International Higher Education, n. 87, Fall 2016.

FERREIRA, A. C. A morada da ética aplicada. Cadernos da Escola do Legislativo, Belo Horizonte, v. 12, n. 19, p. 17-35, jul./dez. 2010.

HALDANE, J. Ética Aplicada. In: BUNNIN, N.; TSUI-JAMES, E. P. (Org.). Compêndio de Filosofia. 4. ed. São Paulo: Loyola, 2013.

KOHLBERG, L. The Psychology of Moral Development: the nature and validity of moral stages - Essays on moral development. v. 2. Harper \& Row Publishers, 1984. 
LIND, G. An introduction to the Moral Judgment Test (MJT). 1998. Available at: https://www.uni-konstanz.de/ag-moral/pdf/Lind-1999_MJT-Introduction-E.pdf. Access in: 17 jun. 2018.

PIAGET, J. Os procedimentos em Educação Moral. In: MACEDO, L. et al. (Org.). Cinco Estudos de educação Moral. São Paulo: Casa do Psicólogo, 1996.

SILVA, P. F. Bioética e valores: um estudo sobre a formação de professores de Ciências e Biologia. 2008. 214 f. Tese (Doutorado em Educação) - Faculdade de Educação da Universidade de São Paulo, São Paulo, 2008.

TANCREDI, R. M. S. P.; REALI, A. M. M. R; MIZUKAMI, M. G. N. Programa de mentoria online: espaço para o desenvolvimento profissional de professoras iniciantes e experientes.

Educação e Pesquisa, São Paulo, v. 34, n. 1, p. 77-95, jan./abr. 2008.

TARDIF, M. Saberes profissionais dos professores e conhecimentos universitários - elementos para uma epistemologia da prática profissional dos professores e suas consequências em relação à formação para o magistério. Revista Brasileira de Educação, n. 13, p. 5-24, jan./ fev./mar., 2000.

VEIGA, I. P. A.; ARAÚJO, J. C. S.; KAPUZINIAK, C. Docência: uma construção éticoprofissional. Campinas, São Paulo: Papirus, 2005.

\section{NOTAS}

${ }^{1}$ Available at: https://noticias.uol.com.br/internacional/ultimas-noticias/2011/05/31/surto-deinfeccao- causado-por-pepino-provoca-a-16-morte-na-europa.htm. Access in: 2 dec. 2017.

${ }^{2}$ The term compliance comes from the English verb to comply, which means to act according to a rule, an internal instruction, that is, to be in compliance is to comply with external and internal laws and regulations. Available at: http://michaellira.jusbrasil.com.br/artigos/112396364/o-quee-compliance-e-como-o-profissional- da-area-deve-atuar. Access in: 17 jun. 2018.

${ }^{3}$ Beauchamp, T. L.; Childress, J. F. Principles of biomedical ethics. N. York: Oxford University Press, 1979.

${ }^{4}$ Available in: https://www.aaeteachers.org/index.php/about-us/aae-code-of-ethics. Access in 27/09/2017.

${ }^{5}$ Available in: http://www.nasdtec.net/?page=MCEE_Doc. Access in 27/09/2017.

${ }^{6}$ Available in: http://www.nea.org/home/30442.htm. Access in 15/02/2017.

${ }^{7}$ Available in: http://www.nysed.gov/content/code-ethics. Access in 15/02/2017.

${ }^{8}$ Available in: https://www.gapsc.com/Ethics/CodeOfEthics.aspx. Access in 16/02/2017.

${ }^{9}$ Available in: https://educationcouncil.org.nz/content/code-of-ethics-certificated-teachers- 0 . Access in 16/02/2017.

${ }^{10}$ Available in: http://colegiodeprofesoresdelperu.org/institucional-codigodeetica.html. Access in 16/02/2017.

${ }^{11}$ Available in: https://www.insper.edu.br/institucional/o-insper/codigo-de-etica-e-conduta/. Access in 15/02/2017.

${ }^{12}$ Available in: http://www.ctteam.org/df/resources/Module5_Manual.pdf. Access in 15/02/2017.

${ }^{13}$ Available in: http://www.ctteam.org/df/resources/Module5_Workbook.pdf. Access in 15/02/2017.

14 Available in:

http://www.waterbury.k12.ct.us/userfiles/3/my\%20files/2015_hr/module $\% 205 \% 20$ scenarios $\% 20$ nto $\% 202015$.pdf ?id $=544776$. Access in 15/02/2017. 
${ }^{15}$ Available in: http://www.fldoe.org/teaching/professional-practices/code-of-ethics-principles-of-professio.stml. Access in 15/02/2017.

${ }^{16}$ Available in: https://www.michigan.gov/documents/Code_of_Ethics_Layout_128009_7.pdf. Access in 15/02/2017.

${ }^{17}$ Available in:

https://education.gov.mt/en/Ministry/Documents/New\%20Code\%20of\%20Ethics\%20Doc\%20EN.pdf. Access in $15 / 02 / 2017$.

Submetido: $10 / 10 / 2018$

Aprovado: 11/03/2019

\section{Contato:}

Paulo Fraga da Silva

Rua Caio Prado, 207, Apto. 46, Consolação

São Paulo | SP | Brasil

CEP 01.303.001 